\title{
Opsonic Activity of Human IgG and IgM Antibody for Type III Group B Streptococci
}

\author{
BASCOM F. ANTHONY AND NELYDIA F. CONCEPCION
}

Department of Pediatrics, UCLA School of Medicine, Harbor-UCLA Medical Center, Torrance, California 90509

\begin{abstract}
We separated IgG and IgM from 10 adult sera containing measurable $(\geq 0.05 \mu \mathrm{g} / \mathrm{mL}$ ) antibody of both isotypes to the type III polysaccharide of group $B$ streptococci. Ig preparations were used to preopsonize ${ }^{3} \mathrm{H}$ labeled type III group B streptococci which were added to adherent monolayers of human, monocyte-derived macrophages. Reproducibly significant phagocytosis, measurable by accumulation of radioactivity and confirmed by electron microscopy, required both antibody (from adult serum or Ig preparation) and complement (from cord serum deficient in specific antibody). All adult IgG and IgM preparations were opsonic in the presence of complement. When a cord serum containing IgG but no IgM antibody was separated by the same procedure, the IgG fraction was opsonic but the fraction that would contain IgM was not. The opsonic activity of $\mathrm{IgM}$ in adult sera persisted after the removal of contaminating IgG4. These observations indicate that both IgG and IgM antibody in adult sera are opsonic for type III GBS and support the hypothesis that IgM deficiency in newborns may be a contributing factor to certain bacterial infections. (Pediatr Res 26:383-387, 1989)
\end{abstract}

\section{Abbreviations}

GBS, group B streptococci

MC, mononuclear cells

The Ig class or isotype of protective antibody against microorganisms which are highly virulent for newborns is relevant to the pathogenesis of neonatal infections. Maternal antibodies of the IgG subclasses are generally well transported across the placenta to term infants, but IgM antibody is not. We previously reported ELISA studies of adult, maternal, and cord serum that suggested that much of the antibody in adults to type III GBS is IgM (1). In this study, IgM and IgG were separated from some of the above sera and evaluated for their capacity to support the phagocytosis of type III GBS by human monocyte-derived macrophages.

\section{MATERIALS AND METHODS}

Serum. Sera from healthy adult volunteers and from the cord blood of normal infants were stored at $-70^{\circ} \mathrm{C}$. Concentrations of IgG, IgM, and IgA in serum and serum fractions were measured by radial immunodiffusion with low-level plates (Kent Laboratories, Inc., Redmond, CA). IgG subclasses were measured by radial immunodiffusion or RIA in the laboratory of Dr.

Received March 13, 1989; accepted June 1, 1989.

Correspondence and reprint requests Bascom F. Anthony, M.D. Department of Pediatrics, Harbor-UCLA Medical Center, 1000 West Carson Street, Torrance, CA 90509.

Supported by Research Grant AI14827 from the NIH.
Douglas C. Heiner (2). Hemolytic complement activity was measured by radial diffusion and expressed as $\mathrm{CH} 100$ (Kallested, Austin, TX).

Antibody assay. IgG and IgM specific antibody to type III polysaccharide of GBS was measured by ELISA as previously described $(1,3)$. Briefly, type III polysaccharide was prepared from culture supernatants of strain $\mathrm{H} 738$ in chemically defined medium. Chromatographically purified polysaccharide was reacted with cyanogen bromide and tyramine to introduce tyrosine groups for better adherence to plastic surfaces; $0.1 \mu \mathrm{g}$ of polysaccharide was added to each well of microtiter plates. After overnight incubation of test sera in multiple dilutions at $4^{\circ} \mathrm{C}$ and washing, the wells were treated with goat antihuman $\mathrm{IgG}$ or goat antihuman IgM, previously conjugated with alkaline phosphatase. Para-nitrophenyl phosphate substrate was added and the absorbance at $405 \mathrm{~mm}$ was measured in an automatic reader. Absorbance values for test serum falling on the linear portion of a standard curve constructed with dilutions of a reference serum were used to calculate antibody concentrations.

Separation of $\operatorname{Ig} G$ and $I g M$. This was done by a modification of the method of Johnson and Libby (4). Serum was heated at $56^{\circ} \mathrm{C}$ for 30 min to inactivate complement, diluted $1: 20$ in 0.05 M EDTA buffer, pH 7.0, and applied to 1-mL columns of QAESephadex A-50 (Pharmacia Fine Pharmaceuticals, Piscataway, NJ). IgG (IgG 1, 2 and 3) was eluted with EDTA buffer, concentrated by ultrafiltration in Minicon B15 concentrators (Amicon Division, W. R. Grace and Co., Danvers, MA) to approximate the original serum concentration of $\mathrm{IgG}$ and dialyzed against $0.01 \mathrm{M}$ PBS, pH 7.4. IgM and other proteins were eluted from the columns with $0.3 \mathrm{M}$. $\mathrm{NaCl}$ in EDTA buffer and dialyzed overnight at $4^{\circ} \mathrm{C}$ against distilled water to precipitate $\operatorname{IgM}(5)$; the precipitate was washed twice with distilled water and dissolved in a volume of PBS calculated to achieve the original serum concentration of IgM. Ig concentrations in these preparations was measured by radial immunodiffusion. To remove contaminating IgG4, some IgM preparations were diluted 1:20 in the manufacturer's binding buffer and applied to ImmunoPure columns of protein A-agarose (Pierce Chemical Co., Rockford, IL); the effluent IgM was dialyzed against PBS.

Streptococci. Strain $\mathrm{H} 738$, isolated from an infant with meningitis, contained type III polysaccharide and was negative for $\mathrm{X}, \mathrm{R}$, and $\mathrm{c}$ proteins. It was labeled during exponential growth in medium RPMI 1640 (GIBCO, Grand Island, NY) with 2, 8 ${ }^{3} \mathrm{H}$-adenine (6) from ICN Biomedicals, Inc., Costa Mesa, CA. Labeled GBS were washed in sterile saline, suspended in RPMI 1640 and stored in aliquots at $-70^{\circ} \mathrm{C}$ for up to $2 \mathrm{mo}$, during which time viability did not decrease significantly and $>95 \%$ of cpm could be pelleted with the bacteria. Before each phagocytosis assay, thawed GBS were opsonized for 15 minutes at $37^{\circ} \mathrm{C}$ in $1: 10$ serum (adult or cord) or the equivalent concentration of separated IgG or IgM in RPMI 1640.

Phagocytosis by human macrophages. This was modified from a previously described assay with rabbit alveolar macrophages (7). Ten $\mathrm{mL}$ of leukocyte-rich plasma from citrated blood of 
normal adult donors was diluted $1: 2$ in physiologic saline, layered over $18 \mathrm{~mL}$ of LSM (Fischer Scientific, Pittsburgh, PA) and centrifuged at $30 \times g$ for $30 \mathrm{~min}$ to separate the MC. The MC band was washed twice in RPMI 1640, and the cells were counted in a hemacytometer with $0.5 \%$ trypan blue. Approximately $6 \times$ $10^{6}$ viable $\mathrm{MC} / \mathrm{mL}$ in $10-15 \mathrm{~mL}$ of RPMI 1640 with $15 \%$ human serum were cultured in $60 \mathrm{~mL}$ Teflon chambers (8) from Savillex Corp., Minnetonka, $\mathrm{MN}$ at $37^{\circ} \mathrm{C}$ and in $5 \% \mathrm{CO}_{2}$. After $4 \mathrm{~d}, 500$ $\mu \mathrm{L}\left(3 \times 10^{6} \mathrm{MC}\right)$ were added to each of several $13-\mathrm{mm}$, round, plastic coverslips (Miles Laboratories, Inc., Naperville, IL) in the wells of Mark II tissue culture trays (Costar Corp., Van Nuys, $\mathrm{CA})$ and incubated at $37^{\circ} \mathrm{C}$ and $5 \% \mathrm{CO}_{2}$ for $90 \mathrm{~min}$. The cells from one to two coverslips were removed with $0.02 \%$ EDTA/ $0.05 \%$ trypsin for counting in the presence of trypan blue. After washing, the $\mathrm{MC}$ monolayers were overlaid with $1 \times 10^{7}$ to 2.5 $\times 10^{7}$ preopsonized, ${ }^{3} \mathrm{H}$ labeled GBS in $500 \mu \mathrm{L}$ of RPMI 1640 (bacterium: $\mathrm{MC}$ ratio of approximately 100:1). The phagocytic trays were agitated at $25 \mathrm{rpm}$ on an orbital shaker in $5 \% \mathrm{CO}_{2}$ at $37^{\circ} \mathrm{C}$. At intervals, coverslips were removed, rinsed four times in saline, air-dried, and placed in vials containing $5 \mathrm{~mL}$ of Scinti Verse II (Fischer) for counting in a Nuclear Chicago Mark II liquid scintillation counter (CD Searle and Co., Des Plaines, IL). All experimental specimens were run in duplicate or triplicate and the results averaged. Controls included GBS preopsonized in RPMI 1640 only and GBS preopsonized in serum or serum fractions but added to coverslips without MC. The opsonic activity of a single serum and the derived $\operatorname{IgG}$ and IgM fractions were compared in the same experiment.

Electron microscopy. Conditions of opsonization and phagocytosis were exactly as described above, but unlabeled GBS were used. After $1 \mathrm{~h}$ of agitation, the MC on coverslips were washed and fixed in a 1:1 mixture of $2.5 \%$ glutaraldehyde and $0.1 \mathrm{M}$ cacodylate buffer for $30 \mathrm{~min}$ and stained with $1 \%$ uranyl acetate and osmium tetraoxide. The preparations were next dehydrated in graded concentrations of ethanol and embedded in SPURR (Polysciences, Inc., Warrington, PA). The sections were separated from coverslips, stained with uranyl acetate and lead citrate, and examined with a JEOL $100 \mathrm{CX}$ electron microscope (Japan Electric Co., Tokyo, Japan).

\section{RESULTS}

Serum antibody levels and separation of $\operatorname{Ig} G$ and $\operatorname{Ig} M$. Table 1 lists the concentrations of IgG and IgM antibody by ELISA determination to type III polysaccharide in the 10 adult sera studied. All contained measurable antibody of both isotypes and the geometric means were $0.86 \mu \mathrm{g} / \mathrm{mL}$ of $\mathrm{IgG}$ specific antibody and $2.67 \mu \mathrm{g} / \mathrm{mL}$ of IgM antibody. These sera were from a collection previously reported (1) which contained a mean of $0.53 \mu \mathrm{g} / \mathrm{mL}$ of IgG and $1.54 \mu \mathrm{g} / \mathrm{mL}$ of IgM type III antibody.

Table 1 also describes the degree of contamination of IgG and IgM preparations by other Ig, expressed as a percentage of the original serum concentrations. IgG preparations were free of detectable IgM with one exception, but most IgM preparations contained small amounts of IgG ( $<4 \%$ of serum concentrations). Three of these preparations (nos. 10, 24, 25) were assayed for $\mathrm{IgG}$ subclasses and were found to contain only IgG4. This was expected because IgG4 copurifies with IgM on QAE-Sephadex A-50 (4).

Assay for phagocytosis by macrophages. Figure 1 illustrates the accumulation of radioactivity by MC monolayers during incubation with ${ }^{3} \mathrm{H}$-labeled, preopsonized type III GBS. Opsonization with an adult antibody-positive serum was followed by a progressive, time-dependent uptake of cpm. When GBs were preincubated with buffer, minimal uptake occurred which was fully 10 -fold less than with serum. When opsonized GBS were added to coverslips with no MC, consistently $<100 \mathrm{cpm}$ accumulated, suggesting that labeled bacteria did not adhere significantly to the plastic surfaces under experimental conditions. In all subsequent experiments, the period of phagocytosis was 60 $\min$.

Figure $2 A$ is a representative electron micrograph of a $\mathrm{MC}$ preparation incubated with GBS preopsonized with the same adult serum as in Figure 1; like the cell shown here, most $\mathrm{MC}$

Table 1. Serum antibody levels and concentrations of Ig isotypes in $\operatorname{IgG}$ and $\operatorname{IgM}$ preparations*

\begin{tabular}{|c|c|c|c|c|c|c|}
\hline \multicolumn{3}{|c|}{ Type III antibody $(\mu \mathrm{g} / \mathrm{mL})$} & \multicolumn{4}{|c|}{$\begin{array}{l}\% \text { of original serum } \\
\text { concentration in: }\end{array}$} \\
\hline \multirow[b]{2}{*}{ Serum no. } & \multirow[b]{2}{*}{$\operatorname{IgG}$} & \multirow[b]{2}{*}{ IgM } & \multicolumn{2}{|c|}{$\begin{array}{c}\text { IgG } \\
\text { preparation }\end{array}$} & \multicolumn{2}{|c|}{$\begin{array}{c}\text { IgM } \\
\text { preparation }\end{array}$} \\
\hline & & & $\operatorname{IgM}$ & $\operatorname{Ig} \mathrm{A}$ & IgG & IgA \\
\hline 24 & 0.42 & 7.30 & 2.2 & 10.5 & $<2.0$ & 1.6 \\
\hline 25 & 10.60 & 5.50 & $\mathrm{ND} \dagger$ & 2.5 & 1.3 & 1.7 \\
\hline 7 & 0.93 & 1.17 & ND & 2.5 & 1.7 & 2.5 \\
\hline 2 & 0.75 & 1.36 & ND & 4.4 & $<2.6$ & 2.2 \\
\hline 4 & 0.46 & 2.52 & ND & 2.8 & 1.9 & 2.8 \\
\hline 9 & 1.14 & 1.62 & ND & 2.6 & 2.4 & 2.6 \\
\hline 18 & 0.06 & 1.12 & ND & 1.3 & $<2.3$ & 1.2 \\
\hline 5 & 0.40 & 6.64 & ND & 2.9 & $<2.9$ & 2.9 \\
\hline 10 & 0.36 & 1.21 & ND & 2.4 & 1.9 & 2.5 \\
\hline 26 & 15.90 & 8.50 & ND & 5.3 & 3.1 & $<3.7$ \\
\hline
\end{tabular}

* Serum antibody concentrations were measured by ELISA and Ig concentrations by radial immunodiffusion. See "Materials and methods." $\uparrow$ Not detected by low-level radial immunodiffusion plates.

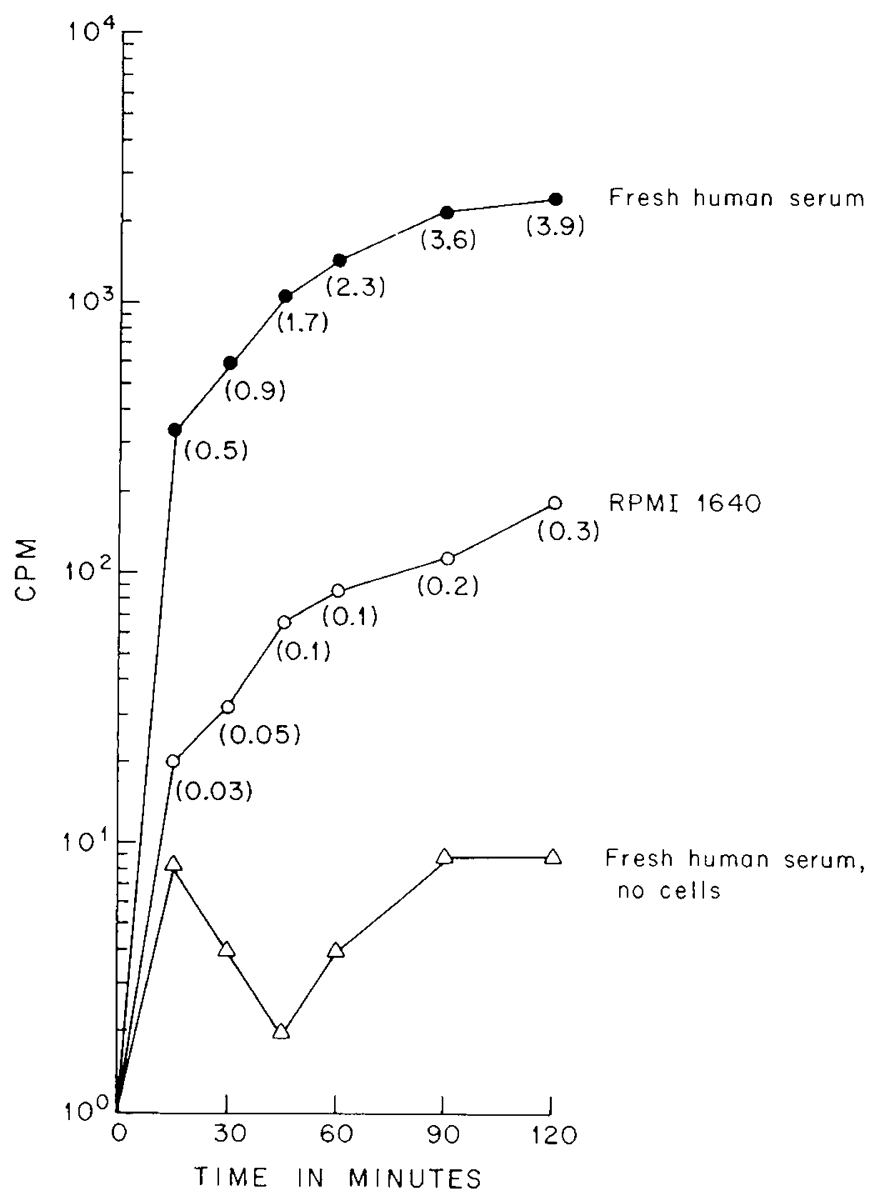

Fig. 1. Uptake of radioactivity by adherent mononuclear phagocytes incubated with ${ }^{3} \mathrm{H}$-type III GBS preopsonized by fresh adult serum (no. 24) or RPMI 1640. The open triangles show the lack of accumulation of radioactivity when opsonized GBS were added to coverslips without mononuclear cells. 
contained several streptococci within phagosomes. As shown in Figure $2 B$, intracellular bacteria were rarely seen in $\mathrm{MC}$ exposed to GBS that had been incubated in buffer only.

Opsonic requirements. Table 2 summarizes a phagocytosis experiment after opsonization with whole adult serum containing $0.9 \mu \mathrm{g} / \mathrm{mL}$ of IgG and $1.2 \mu \mathrm{g} / \mathrm{mL}$ of $\mathrm{IgM}$ antibody with type III specificity. The uptake of ${ }^{3} \mathrm{H}-\mathrm{GBS}$ opsonized with this serum was 7.5 times that with buffer; this was reduced $>85 \%$ when the serum was heated, but was fully restored by supplementing the heated serum with a cord serum containing complement but no detectable type III antibody. The enhancing effect of cord serum was abolished when it was heated (data not shown) and the opsonic activity of cord serum alone was similar to that of buffer (Table 2, last line). These results indicate that maximal phago-
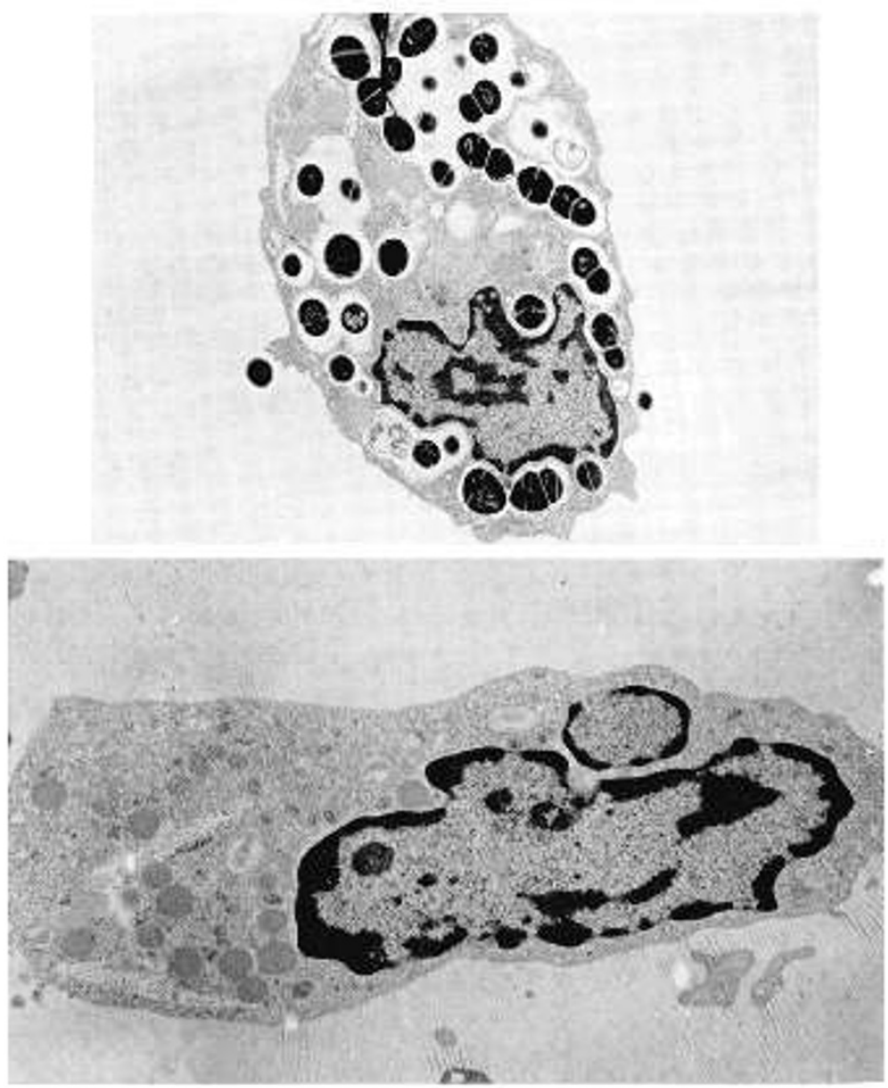

Fig. 2. Electron micrographs of mononuclear phagocytes incubated with type III GBS. $A$, GBS were pre-opsonized in adult serum no. 24. $B$, GBS were preopsonized in RPMI 1640.

Table 2. Opsonic activity of whole human serum* and IgG and IgM fractions

\begin{tabular}{ccr}
\hline $\begin{array}{c}\text { Serum } \\
\text { or fraction }\end{array}$ & $\begin{array}{c}\text { Complement } \\
\text { added } \dagger\end{array}$ & $\begin{array}{c}\text { Uptake of } \\
\text { cpm }(\%)\end{array}$ \\
\hline Fresh & No & $1641(3.6)$ \\
Heated & No & $238(0.5)$ \\
Heated & Yes & $1962(4.2)$ \\
IgG & No & $379(0.8)$ \\
IgG & Yes & $1939(4.2)$ \\
IgM & No & $178(0.4)$ \\
IgM & Yes & $1838(4.0)$ \\
Buffer & No & $220(0.5)$ \\
Buffer & Yes & $290(0.6)$
\end{tabular}

* Serum no. $7 \mathrm{had} 0.93 \mu \mathrm{g} / \mathrm{mL}$ of IgG and $1.17 \mu \mathrm{g} / \mathrm{mL}$ of IgM type III antibody. The numbers in parentheses represent the percent uptake of total radioactivity added to the cell monolayers.

† Human cord serum no. 43 contained $<0.01 \mu \mathrm{g} / \mathrm{mL}$ of IgG type III antibody, no detectable IgM type III antibody and $139 \mathrm{CH} 100 \mathrm{U}$. cytic uptake of type III GBS in this system required opsonization with both antibody (heat-stable component of the adult serum) and complement (heat-labile factor in this cord serum). Table 2 also illustrates the opsonic activity of partially purified $\mathrm{IgG}$ and IgM from the same adult serum. Neither Ig preparation was significantly opsonic alone. When supplemented with cord serum as a complement source, both fractions promoted phagocytosis equivalent to or exceeding that achieved by opsonization with the whole serum.

Opsonic activity of individual sera and preparations of $\operatorname{IgG}$ and $\operatorname{Ig} M$. When different adult sera were tested for opsonic activity against type III GBS, all 10 whole sera promoted more than a 5fold increase in uptake over that seen with buffer alone. The ratio of serum buffer activity ranged from 6 to 23 with a mean ratio of 12.2 .

To compare the contributions of IgG and IgM to the opsonic effect of serum, we subtracted cpm uptake with buffer treatment (nonopsonic phagocytosis) from total $\mathrm{cpm}$ associated with other opsonic mixtures; the results for each Ig preparation were then expressed as a percent of whole serum activity and are shown in Figure 3. The IgG and IgM preparations alone expressed little opsonic activity; many showed no increase over buffer and all had $<20 \%$ of the activity of whole serum. When supplemented with the complement in human cord serum, however, all Ig preparations demonstrated some opsonic effect. For the $\operatorname{IgG}$ preparations, this varied from 33 to $180 \%$ (mean 102\%) of whole serum activity. The opsonic activity of partially purified IgM varied between 33 and $169 \%$ (mean 96\%) of that of the parent serum. No correlation was observed between the specific IgG or IgM serum antibody concentration and the percent of opsonic activity of whole serum achieved by Ig preparations.

Opsonic activity of cord serum and fractions. As shown above (Fig. 3), all adult Ig preparations showed opsonic activity against type III GBS. Inasmuch as we were concerned with the possible introduction of an artifact by the preparative procedures, we fractionated a cord serum that contained appreciable type III IgG antibody $(0.94 \mu \mathrm{g} / \mathrm{mL})$ but no detectable IgM antibody and an appropriately low level of total $\operatorname{IgM}(0.14 \mathrm{~g} / \mathrm{L}$ or $14 \mathrm{mg} / \mathrm{dL})$. As summarized in Table 3, the whole serum was opsonic and the activity was heat-labile and restored with a complement source. In the presence of complement, the IgG preparation reproduced the effect of whole serum. By contrast, the IgM fraction failed to demonstrate impressive opsonic activity in the presence or absence of complement. This suggests that the sep-

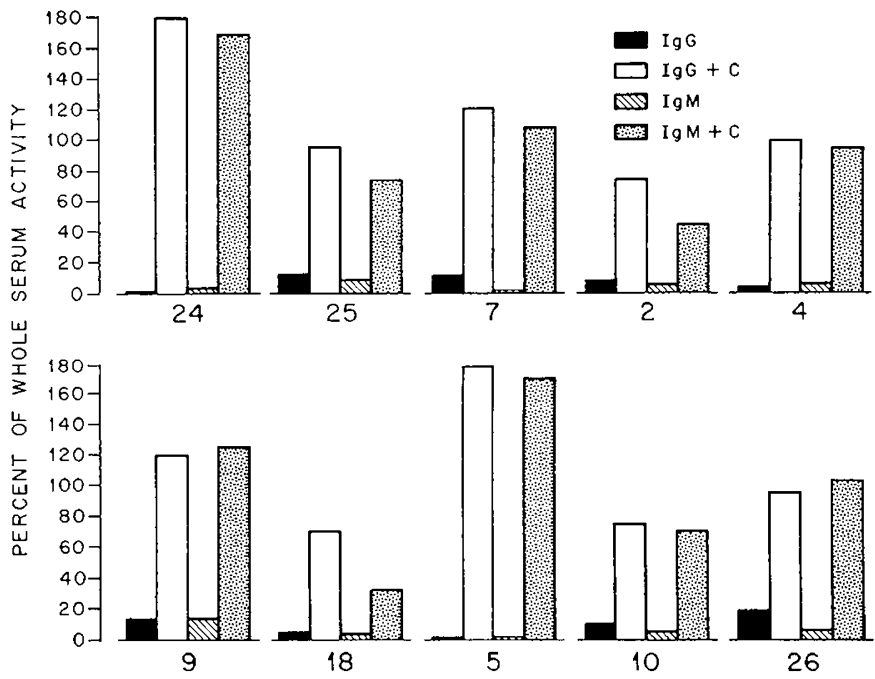

Fig. 3. Opsonic activity of $\mathrm{IgG}$ and $\mathrm{IgM}$ preparations in the presence and absence of complement (cord serum no. 43). Activity is expressed as percentage of bacterial uptake achieved by whole serum from which IgG and IgM were purified. 
aration procedure used for adult sera did not result in falsely positive opsonic tests for the IgM fraction.

Opsonic activity of IgM fraction after removal of $I g G 4$. The consistent presence of $\mathrm{IgG}$ in IgM preparations (usually $<3 \%$ of the serum IgG concentration) could account for the opsonic activity of these fractions. IgG4 in serum accounts for a similar, small proportion of total IgG. We previously showed that the $\mathrm{IgG}$ in most IgM preparations appeared to be $\mathrm{IgG} 4$. To exclude the possibility that contaminating IgG4 was responsible for the opsonic activity of IgM preparations, we removed IgG on protein A-agarose columns and studied the activity of eluted IgM. Table 4 shows that there was no appreciable loss of opsonic activity with $\mathrm{IgG} 4$ removal, indicating that IgM antibody was inherently opsonic (in the presence of complement) for type III GBS.

\section{DISCUSSION}

Inasmuch as GBS in the newborn can be highly invasive and the pyogenic response to local infection may be feeble, the phagocytic function of monocytes and macrophages may be more relevant than granulocytic function. In this report, opsonic activity was assessed from the uptake of ${ }^{3} \mathrm{H}$-labeled GBS by monolayers of human mononuclear phagocytes. MC were first cultured in Teflon containers and then adhered to coverslips; this initial period of maturation in suspension gave better dupli-

Table 3. Opsonic activity of whole cord serum* and fractions

\begin{tabular}{ccr}
$\begin{array}{c}\text { Serum } \\
\text { or fraction }\end{array}$ & $\begin{array}{c}\text { Complement } \\
\text { Added } \dagger\end{array}$ & \multicolumn{1}{c}{$\begin{array}{c}\text { Uptake of } \\
\text { cpm (\%) }\end{array}$} \\
\hline Fresh & No & $2837(5.6)$ \\
Heated & No & $826(1.6)$ \\
Heated & Yes & $2607(5.1)$ \\
IgG $\ddagger$ & No & $819(1.6)$ \\
IgG $\$$ & Yes & $2742(5.4)$ \\
IgM§ & No & $592(1.2)$ \\
IgM§ & Yes & $818(1.6)$ \\
Buffer & No & $598(1.2)$ \\
Buffer & Yes & $705(1.3)$ \\
\hline
\end{tabular}

* Cord serum no. 2 had $0.94 \mu \mathrm{g} / \mathrm{mL}$ of IgG against type III GBS, no detectable IgM antibody and total IgM of $0.14 \mathrm{~g} / \mathrm{L}(14 \mathrm{mg} / \mathrm{dL})$.

+ See footnote to Table 2 .

$\ddagger$ IgG preparation contained no detectable IgM or IgA.

$\S$ IgM preparation contained $2.3 \%$ of serum concentration of $\operatorname{lgG}$ and no detectable IgA.

Table 4. Opsonic activity of whole serum* and fractions, including more highly purified IgM

\begin{tabular}{|c|c|c|}
\hline $\begin{array}{c}\text { Serum } \\
\text { or fraction }\end{array}$ & $\begin{array}{c}\text { Complement } \\
\text { added* }^{*}\end{array}$ & $\begin{array}{l}\text { Uptake of } \\
\text { cpm (\%) }\end{array}$ \\
\hline Heated & No & $417 \quad(1.7)$ \\
\hline Heated & Yes & $3938(10.4)$ \\
\hline $\mathrm{IgG \dagger} \dagger$ & No & $251 \quad(0.7)$ \\
\hline $\mathrm{IgG \dagger}$ & Yes & $2491 \quad(6.6)$ \\
\hline $\operatorname{IgM}(+\operatorname{IgG} 4) \neq$ & No & $227(0.7)$ \\
\hline $\operatorname{IgM}(+\mathrm{IgG} 4) \ddagger$ & Yes & $2809 \quad(7.4)$ \\
\hline $\mathrm{IgM}($ no IgG4)§ & No & $218(0.6)$ \\
\hline $\operatorname{IgM}($ no IgG4)§ & Yes & $2660(7.0)$ \\
\hline Buffer & No & $188 \quad(0.5)$ \\
\hline Buffer & Yes & $240 \quad(0.6)$ \\
\hline
\end{tabular}

* Serum no. 10 had $0.36 \mu \mathrm{g} / \mathrm{mL}$ of IgG and $1.21 \mu \mathrm{g} / \mathrm{mL}$ of IgM type III antibody. See footnote to Table 2.

† The IgG preparation contained no detectable IgM.

$\ddagger$ This IgM preparation (purified by QAE-Sepharose and euglobulin precipitation) contained $3.1 \%$ of the IgG serum concentration.

$\S$ This IgM preparation (further purified on protein A-Sepharose) contained no detectable IgG. cation of phagocytosis than direct cultivation of fresh $\mathrm{MC}$ on coverslips. There was some nonopsonic phagocytosis of GBS treated with buffer only. Significantly greater $(>5$-fold) uptake, confirmed by electron microscopy, required both antibody and complement. The latter was provided by cord serum lacking both IgG or IgM type III antibody.

We previously reported evidence from ELISA studies that, in adult serum, the most prevalent class of naturally occurring antibody to the GBS type III polysaccharide appears to be IgM (1). This study was undertaken to develop unequivocal data on the relative opsonic activity of $\operatorname{IgG}$ and $\operatorname{IgM}$ specific antibody. We were particularly interested in demonstrating the functional activity of IgM, because this isotype is difficult to quantify by ELISA (1).

The adult sera studied contained measurable type III antibody of both isotypes and all of them demonstrated heat-stable opsonic activity against type III GBS. All preparations of partially purified $\operatorname{IgG}$ and IgM were also active but this varied widely. On average, the Ig preparations were equivalent in opsonic activity to the whole parent serum and there was no superiority of IgG or IgM. These results resemble those of Campbell et al. (9) who fractionated sera from infants convalescing from type III GBS infection and measured opsonic activity in a bacterial killing assay with human granulocytes.

The Ig class of protective, antibacterial antibody in the adult assumes special significance for neonatal infections. We have suggested that the predominant adult antibody to type III GBS is IgM (1). This finding has been supported by Boyer et al. (10) who documented the absence of $\operatorname{IgM}$ antibody specific for type III GBS in newborns but its appearance by 6 mo in a small group of infants. It is known that most human antibody specific for the $\mathrm{K} 1$ capsule of Escherichia coli is IgM (11). Using separation procedures similar to those used in this study, Bortolussi et al. (12) recently reported that the opsonic antibody for Listeria monocytogenes type $4 \mathrm{~b}$ in adult serum is IgM, thus explaining the lack of opsonic activity in most neonatal sera. It is reasonable to suggest that infections due to GBS, K1 E. coli, and possibly $L$. monocytogenes may be largely confined to newborn infants because they lack the IgM antibody present and presumably protective in most older individuals. The actual development of infection in the infant may be determined by other factorsexposure to pathogenic bacteria, prematurity and other perinatal variables, and the presence or absence of transplacental IgG antibody.

Acknowledgments. The authors thank Dr. Jefferey Short for the IgG subclass measurements, Birgitta Sjostrand for the electron microscopy preparations, and Dr. Patricia Ferrieri for identification of GBS proteins.

\section{REFERENCES}

1. Anthony BF, Concepcion NF, Wass CA, Heiner DC 1984 Immunoglobulin G and $\mathrm{M}$ composition of naturally occurring antibody to type III group $\mathrm{B}$ streptococci. Infect Immun 46:98-104

2. Beck CS, Heiner DC 1981 Selective immunoglobulin $\mathrm{G}_{4}$ deficiency and recurrent infections of the respiratory tract. Am Rev Respir Dis 124:94-96

3. Anthony BF, Concepcion NF, McGeary SA, Ward JI, Heiner DC, Shapshak $P$, Insel RA 1982 Immunospecificity and quantitation of an enzyme-linked immunosorbent assay for group B streptococcal antibody. J Clin Microbiol

4. Johnson, RB, Jr., Libby R 1980 Separation of immunoglobulin M (IgM) essentially free of $\mathrm{IgG}$ from serum for use in systems requiring assay of IgMtype antibodies without interference from rheumatoid factor. J Clin Microbiol 12:451-454

5. Heide K, Schwick HG 1978 Salt fractionation of immunoglobulins. In: Weir DM (ed) Handbook of Experimental Immunology. Blackwell Scientific Publications, Oxford, pp 7.1-7.11

6. Payne NR, Kim Y, Ferrieri P 1987 Effect of differences in antibody and complement requirements on phagocytic uptake and intracellular killing of "c" protein-positive and -negative strains of type II group B streptococci. Infect Immun 55:1243-1251 
7. Anthony BF 1976 Immunity to the group B streptococci: interaction of serum and macrophages with types Ia, Ib and Ic. J Exp Med 143:1 186-1198

8. Wright SD, Silverstein SC 1982 Tumor-promoting phorbol esters stimulate $\mathrm{C} 3 \mathrm{~b}$ and $\mathrm{C}^{2} \mathrm{~b}^{\prime}$ receptor-mediated phagocytosis in cultured human monocytes. J Exp Med 156:1149-1164

9. Campbell JR, Baker CJ, Metzger TG, Edwards MS 1988 Functional activity of class-specific antibodies to type III, group B streptococcus. Pediatr Res $23: 31-34$
10. Boyer KM, Papierniak CK, Klegerman ME, Rauen ME, Gotoff SP 1987 Development of IgM antibody to group B streptococcus (GBS) type III in human infants. Pediatr Res 21:413A(abstr)

11. Bortolussi $R 1986$ Potential for intravenous gamma-globulin use in neonatal gram-negative infection: an overview. Pediatr Infect Dis 5:S198-S200

12. Bortolussi R, Issekutz A, Faulkner G 1986 Opsonization of Listeria monocytogenes type $4 \mathrm{~b}$ by human adult and newborn sera. Infect Immun 52:493498 